Teologia i Moralność, volumen 16(2021), numer 2(30)

doi: 10.14746/TIM.2021.30.2.7

ORCID: 0000-0002-6186-4422

ANDRZEJ PRYBA

Uniwersytet im. Adama Mickiewicza w Poznaniu

Wydział Teologiczny

\title{
Zasady nowej kultury życia
}

\section{Wstęp}

W wielu regionach świata trwają konflikty zbrojne. Pojawia się coraz więcej kryzysów. Łamane są wrodzone prawa człowieka. Ludzi wykorzystuje się w wojnie hybrydowej. Świat popada w sprzeczność, która polega na tym, iż w tym samym czasie proklamuje się nienaruszalne prawa osoby, deklarując prawo do życia przy jednoczesnym łamaniu i deptaniu tego prawa w najbardziej znaczących momentach jego istnienia, jakimi są narodziny i śmierć. Wobec takiej rzeczywistości, zgodnie z tym co 26 lat temu przekazał Jan Paweł II w encyklice Evangelium vitae, ,trzeba dotrzeć z Ewangelią życia do serca każdego człowieka i wprowadzić ją do samego wnętrza ludzkiego społeczeństwa" (Jan Paweł II 1995, 80). Rodzi się jednak pytanie dotyczące sposobu ewangelizacji w tej mierze. Jak współcześnie wprowadzać kulturę życia? Czy jest to w ogóle możliwe?

Święty Jan Paweł II w czwartym rozdziale encykliki Evangelium vitae zatytułowanej „Mnieście to uczynili. O nową kulturę życia ludzkiego” wyjaśniał, co ma na myśli: „Nową, to znaczy zdolną podejmować i rozwiązywać istniejące dziś, a dawniej nieznane problemy związane z ludzkim życiem; nową, to znaczy bardziej zdecydowanie i czynnie przyjętą przez wszystkich chrześcijan; nową, to znaczy zdolną pobudzić do poważnej i śmiałej konfrontacji kulturowej z wszystkimi” (Jan Paweł II 1995, 95). Pojawia się tu naturalne skojarzenie $\mathrm{z}$ „nową ewangelizacją”. Pojęciem używanym przez Papieża z Polski. Nowa ewangelizacja jest potrzebna dlatego, że przychodzą nowe pokolenia, zmienia się mentalność człowieka, pogłębia się refleksja nad prawdą objawioną (zob. Jan Paweł II 1994a, 92-98). 
Nic więc dziwnego, że chrześcijańska strategia obrony życia musi sięgać do korzeni. Jesteśmy bowiem ,ludem życia, ponieważ Bóg w swojej bezinteresownej miłości dał nam Ewangelię życia, przez którą zostaliśmy przemienieni i zbawieni. Zostaliśmy na powrót zdobyci przez «Dawcę życia» (Dz 3,15), za cenę Jego bezcennej krwi (por. 1 Kor 6,20; 7,23; 1 P 1,19), a poprzez obmycie wodą chrztu zostaliśmy wszczepieni w Niego (por. Rz 6,4-5; Kol 2,12) niczym gałęzie, które z jednego drzewa czerpią soki i zdolność owocowania (por J 15,5). Wewnętrznie odnowieni łaską Ducha, «Pana i Ożywiciela», staliśmy się ludem dla życia i mamy postępować zgodnie z tym powołaniem" (Jan Paweł II 1995, 79). Z drugiej strony natomiast myśl chrześcijańska dotycząca obrony życia winna otwierać się na to, co nowe. Musi bowiem łączyć rozwiązywanie nieznanych wcześniej problemów z przywołanym przez Papieża przekonaniem, że jesteśmy ludem życia i dla życia. Ponadto autentycznie celebrując życie, chrześcijanie winni nabierać odwagi do konfrontacji kulturowej, a z postawy zainteresowania drugim człowiekiem winna wynikać obrona życia ludzkiego. Oto trzy podstawowe zasady kultury życia, na które wskazał Jan Paweł II w swej encyklice o wartości i nienaruszalności życia ludzkiego. Będą one wyznacznikiem namysłu w tym artykule.

\section{Głosić nowość Ewangelii życia}

Jan Paweł II jest przekonany, że Jezus jest jedyną Ewangelią, stąd też nie możemy mówić ani świadczyć o niczym innym. Właśnie głoszenie Jezusa jest głoszeniem życia. Papież zwraca uwagę, iż w Jezusie życie „objawiło się” oraz że On sam jest, ,życiem wiecznym”, które było w Ojcu, a nam zostało objawione (por. $1 \mathrm{~J} 1,1$ ). Ponadto to samo życie zostało udzielone człowiekowi dzięki darowi Ducha. Tym samym zostało ono skierowane ku, „życiu wiecznemu”. W związku z tym życie ziemskie każdego człowieka zyskuje swój pełny sens (Jan Paweł II 1995, 80).

Aby te treści mogły trafić do współczesnego człowieka, należy odwoływać się do racji antropologicznych. Sprawa jest istotna, ponieważ człowiek nie jest współcześnie postrzegany w sposób jednoznaczny. Analizując bowiem założenia ponowoczesnej antropologii, którą najprościej można określić mianem jednowymiarowej, dostrzegamy to, czym się ona charakteryzuje - wieloznacznością i niedookreśleniem (por. Pryba 2010, 51-52). Antropologia ta podważa heteroseksualny model małżeństwa i rodziny. Wynika to $\mathrm{z}$ alternatywności i różnorodności form, których skutkiem jest nieokreśloność struktury, funkcji oraz charakteru rodziny (zob. Slany 2006, 16). Ponadto w związku z wprowadzeniem założeń tejże antropologii w życiu społecznym również w życiu małżeńsko-rodzinnym dokonało się wiele zmian, wskutek czego niektórzy 
badacze postulują konieczność przeformułowania teorii na temat seksualności ludzkiej oraz samej koncepcji małżeństwa i rodziny (por. Slany 2006, 82). Papież Jan Paweł II w adhortacji apostolskiej Familiaris consortio dostrzegał ten sposób myślenia, który w praktyce jest aplikowany do życia społecznego, przynosząc konkretne skutki. Opisywał tę sytuację w sposób następujący: „Nierzadko się zdarza, że mężczyźnie i kobiecie w ich szczerym i dogłębnym poszukiwaniu odpowiedzi na codzienne i trudne problemy życia małżeńskiego i rodzinnego przedkłada się wizje i kuszące propozycje, które w różny sposób zdradzają prawdę i godność osoby ludzkiej. Propozycje te często znajdują poparcie ze strony potężnej i rozgałęzionej sieci środków społecznego przekazu, które niepostrzeżenie narażają na niebezpieczeństwo wolność i zdolność do obiektywnej oceny" (Jan Paweł II 1981, 4).

Kim jest człowiek? To pytanie stawiało i stawia sobie wielu myślicieli. Pośród nich warto przywołać francuskiego antropologa Lévi-Straussa, który stwierdza: „Czymże jestem jako podmiot, jeśli nie [...] stawką w grze kilku miliardów komórek nerwowych, osłoniętych termitierą mojej czaszki i mojego ciała, które służy jej jako robot" (Lévi-Strauss 1984, 479). W kontekście tej wypowiedzi rodzi się w sposób naturalny pytanie, czy tylko tym jest człowiek? By na nie odpowiedzieć, trzeba sięgać po racje zawarte w antropologii teologicznej (por. Jan Paweł II 1995, 82). W tym kontekście należy dalej pytać: Kim jest człowiek w relacji do Boga Jedynego i Troistego objawionego w Chrystusie? Nie oznacza to, że objawienie chrześcijańskie rości sobie pretensje do dysponowania jedynym źródłem wiedzy o człowieku. Przeciwnie, myśl chrześcijańska dotycząca człowieka winna zostać wzbogacona o przemyślenia wywodzące się z filozofii oraz innych nauk humanistycznych. Jednakże, jak słusznie twierdzi Luis Ladaria, ,wszystkie treści należy dostrzegać w nowym i głębszym świetle, a mianowicie w ramach relacji człowieka do Boga. Wyraża się w tym ostateczny i najgłębszy wymiar ludzkiego istnienia, jedyny, jaki ujawnia nam ścisłą miarę tego, czym jesteśmy: uprzywilejowanym przedmiotem miłości Boga, wyłącznym stworzeniem ziemskim, które Bóg chciał dla niego samego, i które zostało wezwane w najgłębszej swej istocie do wspólnoty życia z Bogiem Jedynym i Troistym" (Ladaria 1997, 12). Ponadto należy zwrócić uwagę na najbardziej charakterystyczną cechę antropologii teologicznej, jaką jest odniesienie się do relacji miłości i ojcostwa, którą Bóg pragnie być powiązany z wszystkimi ludźmi w Jezusie Chrystusie. „Człowiek został wezwany «przez łaskę» - z Bożej dobroci - do synostwa Bożego, do uczestnictwa w Duchu Świętym w relacji, która przynależy jedynie Jezusowi" (Ladaria 1997, 13). Jest to ostateczne powołanie człowieka do pełnego uczestnictwa w życiu Bożym przy końcu czasów.

Kolejnym ważnym wymiarem antropologii teologicznej, na którą należy zwrócić uwagę, jest fakt, iż człowiek zaistniał przez obdarowanie Boga. W swej 
dobroci, aktem wolnej decyzji, Bóg zechciał udzielić człowiekowi życiaํ. Został on stworzony na obraz i podobieństwo Boga. Stało się tak przez Chrystusa, ku któremu wszystko zmierza. „Kondycja człowieka jako stworzenia [Bożego] jest głównym czynnikiem determinującym jego istnienie. Dlatego trzeba go teologicznie ujmować w jego właściwym mu usytuowaniu, gdyż jest on nakierowany ku osobowej wspólnocie z Bogiem [...]" (Ladaria 1997, 13-14).

Należy jeszcze zwrócić uwagę na fakt, iż człowiek stworzony przez Boga i jednocześnie wezwany do wspólnoty z Nim znajduje się pod znakiem grzechu, który polega na niewierności Bogu. „Antropologia teologiczna winna rozpatrywać człowieka z uwzględnieniem jego grzeszności oraz zająć się przede wszystkim tym, co tradycja teologiczna nazwała «grzechem pierworodnym»" (Ladaria 1997, 14).

Mając te prawdy na uwadze, trzeba uzasadnić i umocnić szacunek dla życia w świetle rozumu i doświadczenia; ukazać pełnię prawdy o człowieku, odkryć cenną możliwość spotkania i dialogu z niewierzącymi (Mroczkowski 1999, 225). Ten postulat staje się tym bardziej aktualny, im bardziej widoczne stają się skutki oparcia rozumu na samym sobie: oczarowanie jego zdolnością analityczną, redukcją ducha do świadomości i religii do etyki. A z drugiej strony zdaniem księdza profesora Pawła Bortkiewicza, dla obecnej epoki charakterystyczne jest bezkrytyczne absolutyzowanie nowoczesności z pominięciem rozumu (Bortkiewicz 2001, 27). W praktyce oznacza to rezygnację z poszukiwań prawdy i sensu. Stąd też właściwe zrozumienie natury osoby ludzkiej jest pierwszym krokiem w głoszeniu nowej Ewangelii życia.

Ten sposób myślenia dostrzegamy w przepowiadaniu św. Jana Pawła II podczas wygłoszonych katechez środowych „Mężczyzną i niewiastą stworzył ich" (1979-1984), w których wskazywał, iż teologia ciała jest antropologią człowieka stworzonego na obraz i podobieństwo Boże. Papież twierdził, że zamysł uszczęśliwiający Boga w stosunku do człowieka polegał na wspaniałości Jego stworzenia, nadaniu człowiekowi imienia, a także ciała, które jest jedynym sposobem istnienia w świecie. Za pomocą płciowości, jaką jest męskość i kobiecość, Bóg określa osobę mężczyzny i kobiety. W efekcie tego rozgraniczenia powstaje źródło płodności i prokreacji (por. Jan Paweł II 1986, 28).

Teologia ciała jest antropologią człowieka stworzonego na obraz i podobieństwo Boga. „Człowiek, którego Bóg stworzył «mężczyzną i niewiastą», jest obrazem Bożym wyrażonym w ciele «od początku», przy czym mężczyzna i kobieta stanowią jakby dwa różne sposoby ludzkiego «bycia ciałem» w jedności tego obrazu" (Jan Paweł II 1986, 55).

${ }^{1}$ „Nie oznacza to, że nasze istnienie jako stworzeń, nie posiada właściwej sobie konsystencji; zawsze jednak występuje w odniesieniu do Boga, od którego wszystko otrzymujemy" (Ladaria 1997, 13). 
W Roku Rodziny Jan Paweł II skierował List do rodzin. Tam w numerze 9 wyjaśniał kwestie fundamentalne. Przypominał, że poprzez „małżeńską komunię osób mężczyzna i kobieta dają początek rodzinie. Z rodziną zaś wiąże się genealogia każdego człowieka: genealogia osoby. Ludzkie rodzicielstwo zakorzenione jest $\mathrm{w}$ biologii, równocześnie zaś przewyższa ją. [...] Wszelkie rodzenie znajduje swój pierwowzór w Bożym Ojcostwie. Jednakże — w przypadku człowieka - ten «kosmiczny» wymiar podobieństwa do Boga nie definiuje w pełni ludzkiego rodzicielstwa. Gdy z małżeńskiej jedności dwojga rodzi się nowy człowiek, to przynosi on z sobą na świat szczególny obraz i podobieństwo Boga samego: $w$ biologię rodzenia wpisana jest genealogia osoby" (Jan Paweł II 1994b, 9). Wynika z tego, że cielesność człowieka wyraża znacznie więcej niż materialność ludzkiego ciała. Człowiek bowiem przerasta własną naturę. Stąd też doświadczenie tej prawdy dotyczącej godności człowieka domaga dzielenia się nią z innymi. „Trzeba dotrzeć z Ewangelia życia do serca każdego człowieka i wprowadzić ją do samego wnętrza ludzkiego społeczeństwa" (Jan Paweł II 1995, 80). Papież wzywał, by głosić najistotniejszą treść Ewangelii. Jest nią żywy i bliski Bóg, który wzywa człowieka do zjednoczenia ze sobą, dając jednocześnie mu nadzieję życia wiecznego. Ta Ewangelia to proklamacja „niezwykłej więzi Jezusa z każdym człowiekiem, która pozwala rozpoznać w każdej ludzkiej twarzy oblicze Chrystusa; jest ukazywaniem, że «bezinteresowny dar z siebie» to zadanie i miejsce pełnej realizacji własnej wolności" (Jan Paweł II 1995, 80). Jan Paweł II przypominał również w swej znakomitej encyklice, iż konsekwencją Ewangelii życia jest głoszenie prawdy dotyczącej życia ludzkiego, które jest cennym Bożym darem. Jest ono święte i nienaruszalne. Należy je chronić, otaczając troskliwą opieką. Ma ono swój sens, gdy jest związane z miłością. To z miłości rodzi się pełna prawda o ludzkiej płciowości i prokreacji. Ponadto miłość nadaje również sens zarówno cierpieniu, jak i śmierci (por. Jan Paweł II 1995, 80).

Ewangelię życia może obwieszczać osoba, która utrzymuje relację z Jezusem, doświadczając świętości życia. Powinna to czynić językiem zrozumiałym i zarazem pogłębionym. Tak głoszona Ewangelia przenika kulturę człowieka.

\section{Wysławiać Ewangelię życia}

Druga chrześcijańska zasada nowej kultury życia to wysławianie Ewangelii życia. W tym celu wierzący winni pielęgnować w sobie postawę kontemplacji (por. Jan Paweł II 1991, 37). Taka postawa rodzi się z wiary w Boga życia, stwórcy każdego człowieka. Dzięki niej człowiek dostrzega życie w całej głębi. Odkrywa je jako Boży dar. W każdej rzeczy odkrywa odblask Stwórcy, a w każdej osobie żywy obraz Boga (por. Jan Paweł II 1995, 83). 
Nauka o człowieku jako obrazie Boga ukazuje, że Bóg odbija się w całej osobie ludzkiej stanowiącej niepowtarzalny i jedyny świat, którego nie można porównać ze stworzeniem nieosobowym. Człowiek jest bowiem obrazem Stwórcy w całości swego bytu. Dla lepszego zrozumienia idei „obrazu Boga” w człowieku warto przywołać hebrajski sposób myślenia na ten temat, by wejść w rozumienie Biblii. Hebrajczyk nie dokonywał rozróżnienia w człowieku na sferę duszy i ciała, a ujmował go jako całość. Podobnie rzecz się ma, w tym względzie, z przesłaniem Pisma Świętego. Człowiek w całej strukturze psychiczno-duchowej został powołany do istnienia na obraz Boży (por. Grześkowiak 2010, 75).

Trzeba jednak zauważyć, iż mimo podobieństwa do Stwórcy istnieje także różnica pomiędzy obrazem a jego prototypem. Nie ma wątpliwości, że obraz jest zawsze mniej doskonały niż oryginał. Należy tu jednak podkreślić, na co słusznie zwracał uwagę w swym opracowaniu Stanisław Łach, że w starożytności obraz był reprezentantem osoby, którą wyobrażał. Mamy tu bowiem do czynienia z podobieństwem bez upodobnienia oraz z uczestnictwem bez zrównania (Łach 1962, 193). Dzięki temu, że człowiek został stworzony na obraz Boga, otrzymał szczególną pozycję w stosunku do innych stworzeń. Człowiek zajmuje w nim centralne miejsce.

Człowiek powołany do istnienia na obraz Boży ma wpisane w człowieczeństwo powołanie do miłości. Myśl tę rozwinął Jan Paweł II w czasie środowych katechez: „Jest w tym ciele «od początku» zawarta właściwość «oblubieńcza» czyli zdolność wyrażania miłości, tej właśnie miłości, w której człowiek-osoba staje się darem - i spełnia sam sens swego istnienia i bytowania poprzez ten dar" (Jan Paweł II 1986, 161). Należy jednak zauważyć, że relacja oblubieńcza pomiędzy Bogiem a stworzonym przez Niego na swój obraz i podobieństwo człowiekiem jest czymś logicznie wcześniejszym i jednocześnie bardziej podstawowym niż powołanie prowadzące człowieka ku małżeństwu. Temat ten rozwinął Jerzy Bajda w jednej ze swoich książek. Nawiązywał on do szczególnej więzi człowieka ze Stwórcą, która czyni go „kapłanem w znaczeniu podstawowym: kapłaństwo jest pierwszym, fundamentalnym powołaniem człowieka, nawet jeżeli nie przyjmuje postaci świadomej i sformalizowanej w sensie prawno-społecznym. Człowiek, postawiony na szczycie stworzenia widzialnego i wezwany do dialogu miłości z Bogiem, jest $\mathrm{w}$ jakimś głębokim znaczeniu pośrednikiem między Bogiem a światem, a nawet między Bogiem a drugim człowiekiem, co na mocy planu stwórczego ma miejsce w rodzinie" (Bajda 2005, 29).

Biblijny „początek” uświadamia nam hojność Boga w swym obdarowaniu. Darem jest bowiem samo istnienie i życie. Darem jest ukonstytuowanie bytu ludzkiego w formie osobowej na „obraz i podobieństwo Boże”. Bóg, który jest Miłością, obdarowuje więc sobą człowieka. Powołuje go do istnienia 
jako osobę od początku ukierunkowaną na wspólnotę. „To ukierunkowanie ku wspólnocie (komunii) jest od początku cechą planu stwórczego i wyraża się podstawowo i symbolicznie w ustanowieniu pierwszej wspólnoty małżeńskiej.

Jest to właśnie wspólnota daru, ponieważ Bóg daje mężczyznę kobiecie, a kobietę mężczyźnie, co staje się zarazem modelem i normą dla każdego małżeństwa" (Bajda 2005, 179-180).

Odpowiedzią człowieka na to obdarowanie jest również gotowość bycia darem, w sposób bezwarunkowy i nieodwołalny, poprzez przyjęcie postawy służby. Obdarowanie będzie więc implikować pewien charakterystyczny styl życia ludzkiego, które będzie formą daru z siebie dla Boga, będącego Miłością, i dla drugiego człowieka, który jest darem. Taka postawa oczywiście wyklucza uprzedmiotowienie i instrumentalizację drugiej osoby (zob. Pryba 2014, 186-187).

Odkrywając te prawdy, nowy lud odkupionych doświadcza przeżycia zachwytu wobec życia. Wysławia życie poprzez oddawanie czci Bogu, dawcy życia. Tak oto zadziwienie cudem życia przemienia się w postawę dziękczynienia. Serce psalmisty wyrażało to po prostu: „Dziękuję Ci, że mnie stworzyłeś tak cudownie, godne podziwu są Twoje dzieła. I dobrze znasz moją duszę" (Ps 139,14). Śmiertelne życie mimo swych trudów, cierpień oraz przemijalności jest czymś niezwykle pięknym. Jest cudem i wydarzeniem godnym tego, by je opiewać uwielbieniem. „W każdym rodzącym się dziecku i w każdym człowieku, który żyje lub umiera, dostrzegamy obraz Bożej chwały: tę chwałę wysławiamy w każdym człowieku, znaku Boga żywego, ikonie Jezusa Chrystusa" (por. Jan Paweł II 1995, 84).

Chrześcijanie są wezwani do tego, by wyrażać zachwyt i wdzięczność za życie otrzymane w darze. W konsekwencji tego doświadczenia wypływającego z kontemplacji mają przyjmować i przekazywać Ewangelię życia w modlitwie osobistej, wspólnotowej, przez celebracje wspólnotowe, a zwłaszcza „Sakramenty, które są skutecznymi znakami obecności i zbawczego działania Chrystusa Pana w chrześcijańskim życiu: dają ludziom udział w Boskim życiu, zapewniając im potrzebną duchową energię, aby mogli urzeczywistnić pełny i prawdziwy sens życia, cierpienia i śmierci" (Jan Paweł II 1995, 84). Papież jest przekonany, iż potrzebne jest odkrycie autentycznego znaczenia celebracji liturgicznych, a zwłaszcza tych sakramentalnych. Pozwoli to na ich docenienie, a w konsekwencji „,będą mogły wyrażać pełnię prawdy o narodzinach, życiu, cierpieniu i śmierci, pomagając ludziom przeżywać te rzeczywistości jako udział w paschalnej tajemnicy Chrystusa umarłego i zmartwychwstałego" (Jan Paweł II 1995, 84). Ponadto Jan Paweł II zachęca do docenienia i wykorzystania gestów i symboli, które można odkryć w różnych tradycjach kulturowych, jak również i obyczajach ludowych. Papież zwraca uwagę, iż w tych formach porozumiewania się ludzi różnych kultur zawarta jest radość z narodzin nowe- 
go życia, poszanowanie każdego ludzkiego istnienia, troska o potrzebującego, bliskość z cierpiącym i umierającym, współczucie w żałobie oraz pragnienie nieśmiertelności. Ten dialog międzykulturowy jest bardzo potrzebny. Ponadto potrzebne jest budzenie w sumieniach, rodzinach, Kościele, społeczeństwie wrażliwości na wartość ludzkiego życia w każdym momencie jego istnienia. Stąd też wydaje się słusznym inicjatywa obchodzenia każdego roku Dnia Życia (zob. Jan Paweł II 1995, 85).

Sławienie życia dokonuje się w celebracji Eucharystii, jak i wszystkich heroicznych i codziennych gestach miłości. Chrześcijańskie sławienie życia oparte jest na więzi z Panem życia. Jest pieśnią pełną mocy. Wypływa ono bowiem z wiary w Tego, który usensownia ludzkie życie (zob. Mroczkowski 1989, 231-232).

\section{Służyć Ewangelii życia}

Trzecia chrześcijańska zasada nowej kultury życia to służba Ewangelii życia. Chodzi tu o budowanie królestwa Bożego w dziejach polegające na osobistym świadectwie, wyrażające się w różnych formach wolontariatu, działalności społecznej, jak również i politycznej.

Papież w 87 numerze encykliki zwrócił uwagę, iż nie można rozdzielać chrześcijaństwa od polityki. Zaangażowanie chrześcijanina $\mathrm{w}$ politykę powinno być autentycznie chrześcijańskie. Działalność polityczna winna mieć również walor nadprzyrodzony. To bardzo ważna uwaga. „Jest to potrzeba szczególnie nagląca w chwili obecnej, gdyż «kultura śmierci» tak agresywnie atakuje «kulturę życia» i często wydaje się nad nią przeważać" (Jan Paweł II 1995, 87). W tym kontekście ksiądz profesor Jerzy Bajda zwracał słusznie uwagę, iż nie można budować kultury życia poza Chrystusem. „Okazuje się bowiem, że wszelkie dobro uczynione dla człowieka, zwłaszcza dla «jednego z tych najmniejszych» (Mt 25,40), jest uczynione Chrystusowi” (Bajda 2005, 295). Służba życiu jest więc służbą samemu Chrystusowi. Jest to przede wszystkim obrona i jednocześnie promocja życia ludzkiego.

Jan Paweł II nie tylko zachęcał do służby życiu, ale sam wielokrotnie był świadkiem Ewangelii życia. Upominał się o życie człowieka. W przemówieniu do uczestników kongresu „Prawo do życia a Europa” powiedział: „Bezwarunkowe poszanowanie prawa do życia osoby ludzkiej już poczętej, a jeszcze nie narodzonej, jest jednym z fundamentów, na którym opiera się każde cywilizacyjne społeczeństwo [...]. Nie trzeba powoływać się na zasady wiary chrześcijańskiej, by zrozumieć te podstawowe prawdy. Odwołując się do nich, Kościół nie dąży do wprowadzenia państwa chrześcijańskiego, pragnie jedynie popierać rozwój państwa ludzkiego. Takiego państwa, które uznaje za swój 
główny obowiązek obronę podstawowych praw osoby ludzkiej, a zwłaszcza najsłabszych" (Jan Paweł II 1987, 25).

Świadectwo miłości wobec życia możliwe jest u ludzi, którzy sami nie boją się życia. Warto tu zauważyć, że ludzkie samostanowienie związane jest $\mathrm{z}$ trudem istnienia i wymaga męstwa bycia. Zawsze pozostaje napięcie pomiędzy tym, kim człowiek jest, i tym, kim powinien być. W tym kontekście istotnym jest wychowanie młodego pokolenia do pełni człowieczeństwa. „Wszystko to stwarza konieczność podjęcia cierpliwej i odpowiedzialnej pracy wychowawczej, która zachęci wszystkich i każdego do wzięcia na własne barki brzemion innych (por. Ga 6,2); wymaga nieustannej troski o powołania do służby, zwłaszcza wśród młodzieży; nakazuje realizację konkretnych projektów i inicjatyw, trwałych i ożywianych ewangelicznym duchem" (Jan Paweł II 1995, 88).

Papież wskazując na służbę Ewangelii życia, przywołał struktury i miejsca służące życiu. Winny tam pracować osoby bezinteresownie zaangażowane i świadome znaczenia Ewangelii życia dla dobra tak poszczególnych jednostek, jak i całego społeczeństwa. Szczególna odpowiedzialność, zdaniem Papieża, spoczywa na pracownikach duszpasterstwa rodzin, poradni małżeńsko-rodzinnych czy też personelu służby zdrowia. Jan Paweł II dostrzega, iż we współczesnym kontekście społeczno-kulturowym nauka i sztuka medyczna tracą swój wymiar etyczny. Stąd też pojawiają się pokusy manipulowania życiem. Dlatego należy odwoływać się do zawsze aktualnej przysięgi „Hipokratesa, według której każdy lekarz jest zobowiązany okazywać najwyższy szacunek życiu ludzkiemu i jego świętości” (Jan Paweł II 1995, 89).

Służba Ewangelii życia jest dziedziną rozległą i jednocześnie złożoną. Stwarza ona możliwości współpracy ekumenicznej, jak również dialogu pomiędzy wyznawcami różnych religii oraz z ludźmi dobrej woli. Obrona i promocja życia jest zadaniem i odpowiedzialnością wszystkich. Jest to trudne wyzwanie, jednak konieczne, aby uniknąć klęski cywilizacji oraz jej nieobliczalnych konsekwencji. Istnieje potrzeba zgodnej współpracy wszystkich, którzy wierzą w wartość życia (zob. Jan Paweł II 1995, 91).

\section{Zakończenie}

Na początku artykułu zostało postawione pytanie, czy współcześnie można skutecznie wprowadzić w życie zasady nowej kultury życia? Analiza tekstów wskazuje, że jest to możliwe. Muszą być jednak spełnione konkretne warunki. Ewangelię życia może głosić ten, kto utrzymuje więź z Chrystusem i zarazem doświadcza świętości życia. Głoszenie Jezusa jest także głoszeniem życia, bowiem w Jezusie życie „objawiło się” oraz On sam jest „życiem wiecznym”. 
Ewangelizator winien to czynić językiem zrozumiałym a jednocześnie pogłębionym, bazując na antropologii teologicznej. Ten kto autentycznie ewangelizuje, przepaja tym samym Ewangelią kulturę człowieka.

\section{PRINCIPLES OF THE NEW CULTURE OF LIFE}

\section{SUMMARY}

The author of the article, referring to the encyclical of John Paul II "Evangelium vitae", asks questions about contemporary culture with particular emphasis on the culture of life. How to introduce a culture of life today? Is it possible? The intuitions contained in the Gospel of life were helpful in answering these questions. The good news of life should be proclaimed and praised constantly. Having known it, one should serve her.

Keywords: culture, culture of life, The Gospel of life

Słowa kluczowe: kultura, kultura życia, Ewangelia życia

\section{BIBLIOGRAFIA}

Bajda, Jerzy. 2005. Rodzina miejscem Boga i człowieka, Łomianki: Fundacja „Pomoc Rodzinie”.

Bortkiewicz, Paweł. 2001. Ideowy obraz współczesnej kultury euroatlantyckiej, W: Moralne aspekty przemian cywilizacyjnych, red. Janusz Nagórny i Andrzej Derdziuk, 21-34. Sandomierz: Wydawnictwo Diecezjalne.

Grześkowiak, Jerzy. 2010. „Tajemnica to jest wielka”. Sakramentalne przymierze matżeńskie, Opole: Redakcja Wydawnictw Wydziału Teologicznego Uniwersytetu Opolskiego.

Jan Paweł II. 1981. Adhortacja apostolska „Familiaris consortio” o zadaniach rodziny $w$ świecie wspótczesnym.

Jan Paweł II. 1986. Mężczyzna i niewiasta stworzyt ich. Odkupienie ciała a sakramentalność matżeństwa, Città del Vaticano.

Jan Paweł II. 1988. Przemówienie do uczestników kongresu „Prawo do życia a Europa” (18.12.1987). L'Osservatore Romano (PL) 2, 25.

Jan Paweł II. 1988. Przemówienie do uczestników kongresu „Prawo do życia a Europa” (18.12.1987). L'Osservatore Romano (PL) 2 (1988), 25.

Jan Paweł II. 1991. Encyklika ,Centesimus annus”.

Jan Paweł II. 1994a. Przekroczyć próg nadziei, Lublin: Wydawnictwo Katolickiego Uniwersytetu Lubelskiego.

Jan Paweł II. 1994b. List do rodzin „Gratissimum sane”.

Jan Paweł II. 1995. Encyklika „Evangelium vitae” o wartości i nienaruszalności życia ludzkiego.

Ladaria, Luis F. 1997. Wprowadzenie do antropologii teologicznej, tłum. Arkadiusz Baron. Kraków: Wydawnictwo WAM.

Lévi-Strauss, Claude. 1984. Tristesse Tropiques. Paris: Plon. 
Łach, Stanisław. 1962. Księga Rodzaju, t. 1, cz. 1. Poznań: Wydawnictwo Pallottinum.

Mroczkowski, Ireneusz. 1999. Chrześcijańskie zasady nowej kultury życia. O odwagę nowego stylu życia. W: Evangelium vitae. Tekst i komentarze, red. Tadeusz Syczeń i Janusz Nagórny, 223-236. Lublin: Redakcja Wydawnictw Katolickiego Uniwersytetu Lubelskiego.

Pryba, Andrzej. 2010. Matżeństwo i rodzina w kryzysie?. „Teologia i Moralność” 7, 45-58.

Pryba, Andrzej. 2014. Instytucjonalne działania wobec rodziny na terenie województwa wielkopolskiego w latach 1999-2009. Inspiracje teologiczne w praktyce powiatowych centrów pomocy rodzinie. Pelplin: Wydawnictwo Bernardinum.

Slany, Krystyna. 2006. Alternatywne formy życia matżeńsko-rodzinnego w ponowoczesnym świecie. Kraków: Wydawnictwo Nomos.

Andrzej Pryba - kapłan Zgromadzenia Misjonarzy Świętej Rodziny, doktor habilitowany nauk teologicznych w zakresie teologii moralnej. Profesor Uniwersytetu im. Adama Mickiewicza w Poznaniu (Zakład Filozofii i Dialogu). Prodziekan ds. rozwoju i współpracy międzynarodowej Wydziału Teologicznego UAM. Przewodniczący Rady Programowej Kierunku Dialog i Doradztwo Społeczne. Członek Zarządu Stowarzyszenia Teologów Moralistów oraz wiceprezes Zarządu Polskiego Stowarzyszenia Familiologicznego. Redaktor naczelny czasopisma naukowego „Teologia i Moralność”.

Główne kierunki badań dotyczą problematyki moralnospołecznej życia małżeńskiego i rodzinnego, normatywno-aksjologicznej etyki życia rodzinnego oraz poradnictwa rodzinnego. 